Vol: 2, Issue: 4

April/2021

https://ijbssrnet.com/index.php/ijbssr

DOI: http://dx.doi.org/10.47742/ijbssr.v2n4p2

http://iarpnet.org/

\title{
The Determination of Audit Quality and its Impact on Audit Report Presentation: Empirical Study at Public Accountant Office in BEKASI City
}

\author{
Dewi Rejeki \\ Faculty of Economics \\ University of Krisnadwipayana \\ Campus Unkris Jatiwaringin \\ Po Box 7774/Jat Cm Jakarta 13077 \\ Email: dewi.and71@gmail.com \\ Indonesia
}

\section{A R T I C L E I N F O \\ Article historv: Article \\ Received: $\quad 7$ April 2021 \\ Revised: $\quad 20$ April 2021 \\ Accepted: $\quad 29$ April 2021}

DOI: 10.47742/ijbssr.v2n4p2

Orcid ID: https://orcid.org/0000-0002-9726-1500

\begin{abstract}
A B S T R A C T
The purpose of this study is to prove the effect of professionalism, competence, independence, and work experience of auditors on audit quality at a public accountant office in Bekasi City, which consists of senior auditors, junior auditors, partners, and supervision.

The method used is a quantitative method by distributing questionnaires. The data analysis technique used is descriptive statistics and hypothesis testing.

This study proves both partially and simultaneously that the professionalism, competence, independence, and work experience of auditors affect audit quality.

Keywords: professionalism, competence, independence, work experience of auditors and audit quality
\end{abstract}

\section{Introduction}

Financial reports are a form of management accounting that provides information to users in making decisions. Therefore, the financial statements that are presented must be relevant and reliable. To measure the required characteristics and provide assurance that management's financial statements are relevant and dependable and can increase all interested parties' confidence, users use the services of an external auditor.

The auditors' profession is currently widely known and trusted by the wider community, especially for service users, one of which is companies that want to audit their financial statements. Because of this profession, the public and users of public accounting services expect a free and impartial assessment from any party. Users of the public accounting profession certainly expect that the financial statements audited by the auditor are free from material misstatement, can be trusted to be accurate, and are following auditing standards applicable in the country of Indonesia.

For an auditor, professionalism is a must in carrying out their duties. Auditor professionalism refers to professional abilities and behavior. Capability is defined as knowledge, experience, adaptability, technical ability, technological capability, and allowing auditors' professional conduct to include additional factors such as transparency and responsibility. This is very important to ensure public trust (Baotham, 2007).

This professionalism will be increasingly vital if it is related to individuals' work, which in turn can provide confidence in the financial statements of a company where the auditor works. Therefore, an auditor in each of his duties must be professional to produce reliable financial reports. The higher the auditor's professional view, the higher the confidence of users of financial statements in the auditor.

Besides, an auditor must have competence, which is the qualification needed by the auditor to carry out the audit properly and is also helpful for maintaining the auditor's objectivity and integrity. This competence must be continuously improved by following various special training held by professional accounting organizations such as the Indonesian Institute of Public Accountants (IAPI). By following special training, an auditor will add insight and knowledge to his field's development of expertise. This competence will affect the independence of an auditor in carrying out his duties.

An incompetent auditor will not be able to act independently. This is because these auditors will tend to rely on others' opinions in completing their audit tasks due to their limited knowledge and expertise. The independence of an auditor is very much needed in carrying out his audit duties. A neutral and unbiased attitude and avoiding conflicts of interest in planning, implementing, and reporting audit results are the key to the public's trust who uses financial statements.

Apart from professionalism, competence, and independence, work experience is also influential for an auditor in producing quality audit reports. With good work experience, an auditor will have audit expertise in detecting any problems that arise. Based on this experience, an auditor's expertise will increase and expand apart from the formal education that has been obtained. So the longer an auditor's flying hours in conducting an audit, the more experience he will get because from there, the auditor will face many cases and solutions. 
Vol: 2, Issue: 4

April/2021

https://ijbssrnet.com/index.php/ijbssr

DOI: http://dx.doi.org/10.47742/ijbssr.v2n4p2

An auditor who has professionalism, independent competence, and work experience will affect the resulting audit quality. Good audit quality will affect the trust of users of financial statements. The existence of audit failures that have emerged so far has resulted in the quality of the audit, which is influenced by several of the factors above. For the quality of the audit reports produced by the auditors, the auditors must carry out their duties in a professional manner and be independent of clients, meet auditing standards in auditing financial statements, obtain sufficient competent evidence to express an opinion on financial statements, and carry out a systematic process in a complete audit and carry out or perform auditor responsibilities.

Research on audit quality has been conducted by several previous researchers such as research conducted Furiady \& Kurnia (2015), Safaroh, Susilawati \& Halim (2016) and Pandoyo (2017); Ningrum \& Wedari (2017); Iryani (2017); Zahmatkesh \& J. Rezazadeh (2017); Mardijuwono \& Subianto (2018), and Sriyanti \& Jianto (2019); Giovani \& Rosyada (2019); wherefrom the results of these studies the factors that become benchmarks for audit quality are objectivity, independence, professionalism, professional due, accountability, and auditor experience.

Based on this, researchers are interested in reviewing audit quality by analyzing and proving that it focuses only on independence, objectivity, professionalism, and auditor work experience by taking the object of auditors in 8 (eight) Public Accounting Office the Bekasi City area. For this reason, the formulations of the problems raised are as follows:

1. Is there an effect of professionalism on audit quality?

2. Is there an effect of competence on audit quality?

3 . Is there an effect of independence on audit quality?

4. Is there an effect of work experience on audit quality?

5. Are there any effects of professionalism, competence, independence, and work experience on audit quality?

\section{Literature Review}

\section{Audit Quality}

Tandiontong (2016, p. 48) states that many parties define audit quality, but there is no clear definition of audit quality itself. This is due to the absence of a general understanding of the factors that make up audit quality, and there is often role conflict between various users of the audit report. However, there are several definitions of audit quality. Namely, the first is an auditor's ability to carry out his duties. In conducting an audit, the auditor can find client errors and report them.

De Angelo (1981) has defined audit quality as the probability that an auditor finds and reports about a violation in his client's accounting system. His research results indicate that a large Public Accounting Office will present a more excellent quality of audit than a small Public Accounting firm. Audit quality is also defined as the possibility (joint probability) that the auditor will find violations in the client's accounting system and report them in the audited financial statements (De Angelo, 1981 in Alim et al. 2007). Kane and Velury (2005) in Sari (2011) define audit quality as the external auditor's capacity to detect material errors and other forms of irregularities. Russel (2000) in Sari (2011) states that audit quality is a guarantee function where the quality will be used to compare the actual conditions with the conditions.

Farida et al. (2016) stated that audit quality is the possibility of the auditor finding various clients' violations in presenting financial statements. The auditor's report these violations in the audited financial statements. Agusti \& Pertiwi (2013) states that audit quality is the implementation of an audit carried out following standards to disclose and report in the event of a violation committed by a client. According to the Public Accountant Professional Standards (SPAP), audit quality states that audits conducted by auditors are said to be of quality if they meet auditing standards and quality control standards.

Deis and Giroux (1992) researched four things considered to have a relationship with audit quality, namely (1) the length of time the auditor has examined a company (tenure), the longer an auditor has audited the same client, the resulting audit quality. The lower, (2) the number of clients, the more the number of clients, the better the audit quality because the auditor with a large number of clients will try to maintain his reputation, (3) the financial health of the client, the healthier the client's financial condition, the more likely the client will be to pressure auditors not to comply with standards, and (4) review by third parties, the quality of the audit will improve if the auditor finds out that a third party will review the results of his work.

\section{Professionalism}

Professionalism can be interpreted as a careful and thorough attitude by thinking critically and evaluating audit evidence, being careful in duties, not being careless in conducting examinations, and having determination in carrying out responsibilities. Carefulness requires the auditor to be alert to significant risks. With a caring attitude, auditors will reveal various kinds of fraud in the presentation of financial statements more easily and quickly. Therefore, in evaluating audit evidence, the auditor is required to have sufficient confidence.

Baotham (2007) states that auditor professionalism refers to professional abilities and behavior. Capability is defined as knowledge, experience, adaptability, technical ability, technological capability, and allowing auditors' professional conduct to include additional factors such as transparency and responsibility. These are essential to ensure public trust.

Professionalism is an attitude of being responsible for what has been assigned to him. The philosophy of professionalism will make decisions based on its considerations, namely based on the first dedicated to the profession, auditors who serve their career will carry out the totality of work wherewith this totality they will be more careful and wise in conducting so that they can produce quality audits. So if the higher the dedication to the profession, the higher the auditors' professionalism (Agusti \& Pertiwi, 2013).

\section{Competence}

Competence is needed to demonstrate an auditor's ability to provide a good level of performance (Kharismatuti and Hadiprajitno, 2012). Competence is the ability to carry out or perform a job or task based on skills and knowledge and is supported by the work attitude demanded by the job. Thus, 
Vol: 2, Issue: 4

April/2021

https://ijbssrnet.com/index.php/ijbssr

DOI: http://dx.doi.org/10.47742/ijbssr.v2n4p2

http://iarpnet.org/

competence is the expertise, skills, knowledge possessed by professionalism in a particular field as the most important, as an advantage in that field (Wibowo 2018: 324). Competence is knowledge, skills, and abilities related to work and skills needed for non-routine jobs (Samsi, 2017).

Based on this explanation, competence can be seen from various points of view. This research will use competence from the point of view of individual auditors because auditors are subjects who conduct audits directly and are directly involved in the audit process so that good competence is needed to produce quality audits.

\section{Independence}

Independence is an attitude-free from influence, not controlled by other parties, not dependent on others. Independence also means the auditor's honesty because there are objective judgments impartially by the auditor in formulating and expressing opinions. The length of the relationship with the client is measured by the amount of the audit fee, sanctions, and the threat of changing the auditor from the client and the client's facilities. The co-auditors' review is measured by the benefit of evaluating the fellow auditors and the consequences of lousy auditing methods. Non-audit services are measured by how auditors provide non-audit services and provide other services to improve client financial statement information (Fabiano Fanetto Yonchers, 2019, page 4). Independence, in general, can also be interpreted as a mental attitude that is free from influence, uncontrolled, and independent of other parties. General requirements for auditor independence prohibit the auditor from engaging in various audit activities for an entity when there is an unresolved conflict of interest relating to that entity. This is because the audit's value is highly dependent on the public's perception of auditor independence (Arens, 2011).

In the book, Public Accountant Professional Standards (SPAP) Auditing Standards (SA) Section 220, Auditing Standard Statement (PSA) No. 04 Paragraph 2 (2007), explains that "Independence means not easily influenced, because he carries out his work for the public interest (differentiated in terms of practicing as an internal auditor)." Thus, he is not allowed to side with anyone's interests because no matter how perfect his technical skills are, he will lose impartiality, which is most important to defend his freedom of opinion.

\section{Work Experience}

Experience is a good way of learning for internal auditors, which will make auditors rich in audit techniques. The higher the auditor's experience, the more capable and proficient the auditor is in mastering his duties and auditing activities. Experience also makes auditors able to face and resolve obstacles and problems in carrying out their duties and control emotional tendencies towards the parties being examined. In addition to knowledge and expertise, auditors' experience is a relevant contribution to improving the competence of auditors.

Auditor experience is the combined accumulation obtained through interactions, making the auditor have a better understanding of the audit. Sutrisno (2012) states that an experienced audit is "an auditor who has a better experience. They are also better able to provide a reasonable explanation for the errors in the financial statements. They can classify mistakes based on the audit objectives and the structure of the underlying accounting system.

Psychologically, the experience will shape a person's personality. It will make a person wiser in both thinking and acting because a person's experience will feel his position when he is in a good state and when he is in bad condition. A person will be more careful in acting when he feels he has made a fatal mistake. He will feel happy when he managed to find a solution to a problem and will do the same when the same problem occurs. He will be satisfied when winning arguments and feel proud when rewarded for his work (Bonner and Lewis, 1990; Farhan, 2004 in Noviari et al., 2005).

Purnamasari (2005) concludes that an employee who has high work experience will have advantages in several ways, including detecting errors, understanding errors, and looking for causes of errors (in Asih, 2006: 12). So experience is essential for a profession that requires very high professionalism, such as public accounting because it will significantly affect how the quality of an auditor's work.

\section{Conceptual Framework}

The conceptual framework based on the formulation of the problem above in this study is as follows:

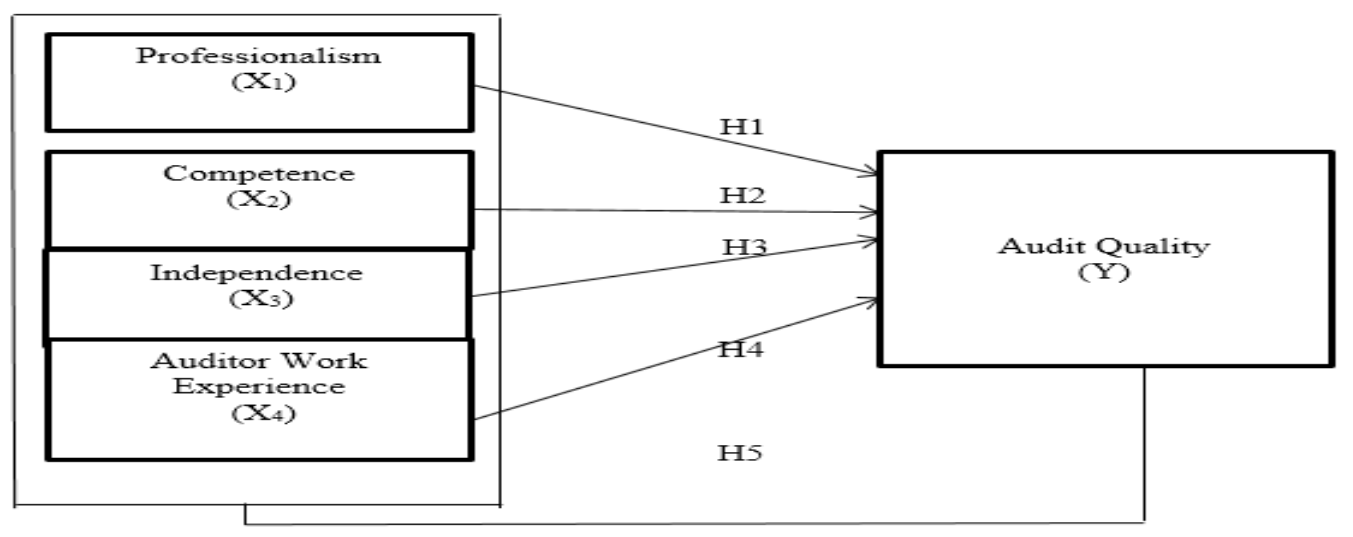

Fig 1. Conceptual Framework 
Vol: 2, Issue: 4

April/2021

https://ijbssrnet.com/index.php/ijbssr

DOI: http://dx.doi.org/10.47742/ijbssr.v2n4p2

http://iarpnet.org/

\section{Hypothesis}

H1: There is an influence of professionalism on audit quality.

$\mathrm{H} 2$ : There is an influence of Competence on Audit Quality.

H3: There is an effect of Independence on Audit Quality.

H4: There is an influence of the Auditor's Work Experience on Audit Quality.

H5: There is an influence of the Auditor's Professionalism, Competence, Independence and Work Experience on Audit Quality

\section{Research Methods}

This study's population are auditors who are limited only to Public Accounting Office in the Bekasi City area, where the population is 43 Public Accounting Offices registered with OJK in 2019 with 3-10 auditors in each Public Accounting Firms. In this study, the samples taken were senior auditors, junior auditors, partners, and supervision.

The sampling technique used the purposive sampling method with the following criteria:

1. Auditors who have at least one year of work experience.

2. Auditor with a minimum education of Strata 1.

3. All levels of auditors, including Partner, Supervision, Senior Auditor, and Junior Auditor.

Based on the above criteria, a sample of 8 Public Accounting Office was obtained with each Public Accounting Office with more than two auditors. In collecting data sources, researchers used primary data. While the scale used in measuring the answer value scale is given using a five-scale score system (Likert): The type of research used is quantitative research with a crosssectional study design. The data collection methods used in this study were questionnaires and observations. The researcher will provide a set of written statements to the respondent to answer then. Data collection is carried out by direct observation of the research object to obtain information by distributing questionnaires, and the rate of return of the questionnaire will be higher. The data analysis technique used is descriptive statistics, data testing with validity and reliability tests, normality test, classical assumption test, hypothesis testing either partially or simultaneously, and determination coefficient test.

\section{Results and Discussion}

Processed data is data whose contents are complete and suitable for processing, so not all returned questionnaires are ideal for processing. Based on the data collected in this study, the questionnaire was distributed in several 54 copies based on the number of auditors from several Public Accounting Office in Bekasi City. Still, only 40 auditors were willing to answer or fill out the questionnaire given. The description of the characteristics of the questionnaire data can be seen in the following table:

Table-1. Description of Questionnaire Distribution

\begin{tabular}{|r|l|c|c|c|}
\hline No & $\begin{array}{l}\text { Name Public } \\
\text { Accounting } \\
\text { Office }\end{array}$ & $\begin{array}{c}\text { Questionnaires } \\
\text { Sent }\end{array}$ & $\begin{array}{c}\text { Questionnaires } \\
\text { Are Returned }\end{array}$ & $\begin{array}{c}\text { Questionnaires } \\
\text { Are Processed }\end{array}$ \\
\hline 1. & Angelina Yansen & 6 & 5 & 5 \\
\hline 2. & $\begin{array}{l}\text { Irwanto, Hary } \\
\text { dan Usman }\end{array}$ & 8 & 8 & 5 \\
\hline 3. & Wisnu \& Katili & 7 & 6 & 6 \\
\hline 4. & $\begin{array}{l}\text { Jeptha nasib \& } \\
\text { junihol }\end{array}$ & 7 & 7 & 5 \\
\hline 5. & $\begin{array}{l}\text { Jojo Sunarjo \& } \\
\text { Rekan }\end{array}$ & 6 & 5 & 5 \\
\hline 6. & $\begin{array}{l}\text { Mohammad } \\
\text { Kudithama Al } \\
\text { Kautsar }\end{array}$ & 7 & 6 & 5 \\
\hline Putu Wijaya & 6 & 6 & 5 \\
\hline 8rs. Abdul & $\begin{array}{l}\text { Muntalib \& } \\
\text { Yunus }\end{array}$ & & 50 & 40 \\
\hline
\end{tabular}

Source: Primary Data Processed (2020)

The questionnaire was given and received back by the means that the results are valid. This can be seen from the validity researcher at a predetermined time and adjusted to the intended test results that all question items have a calculated R-value above Public Accounting Office work schedule. Questionnaires were $0.30(>0.30)$.

distributed starting from 21 July 2020 -17 August 2020.

\section{Data Quality Test Results}

Based on the results of the validity test calculation, the score of each instrument statement item from 40 respondents, the total number of statements for the variable 44 statements with a total score of each respondent obtained more than 0.30 , which
Based on the results of the reliability test, it can be seen that the value of the coefficient alpha $(\alpha)$ of the professionalism variable is 0.636 , the competency variable is 0.614 , the independent variable is 0.615 , the auditor work experience variable is 0.645 , and the audit quality variable is 0.681 . This 
Vol: 2, Issue: 4

April/2021

https://ijbssrnet.com/index.php/ijbssr

DOI: http://dx.doi.org/10.47742/ijbssr.v2n4p2

http://iarpnet.org/

indicates that all variables are said to be reliable because they have a Cronbach Alpha value greater than 0.60 (> 0.60).

\section{Multiple Linear Regression Test Results}

Based on the results of the analysis, the regression equation is obtained as follows:

$$
\mathrm{Y}=47.775+0.140(\mathrm{X} 1)+0.058(\mathrm{X} 2)+0.445(\mathrm{X} 3)+
$$

$0.274(\mathrm{X} 4)$ follows:

From the regression equation, it can be explained as

1. Costant has a value of 47.775 , this indicates that if $\mathrm{X} 1$ (Professionalism), X2 (Competence), X3 (Independence), $\mathrm{X} 4$ (Auditor Work Experience), the value is zero, then $\mathrm{Y}$ (Audit Quality) has a value of 47.775 .

2. Professionalism regression coefficient (X1) of 0.140 indicates a positive sign. It means that every 1-unit increase of professionalism will increase the audit quality by 0.140 and other influencing factors are considered constant.

3. Competency regression coefficient (X2) of 0.058 shows a positive sign, this means that every increase of 1 competency unit will increase the audit quality by 0.058 and other influencing factors are considered constant.

4. The independence regression coefficient (X3) of 0.445 shows a positive sign. It can be interpreted that every 1 unit increase of independence will increase the audit quality by 0.445 and other influencing factors are considered constant.

5. Auditor work experience regression coefficient (X4) of 0.274 shows a positive sign. It means that every increase of 1 unit of auditor work experience will increase the audit quality by 0.274 and other influencing factors are considered constant.

Based on the results of data analysis, that the value of the professionalism variable has a significant level of 0.027 . This value is less than 0.05 . This means that the research hypothesis which states professionalism has a partial effect on audit quality is accepted. In this case, the t count has a value of 4.490, while the $t$ table's value is 2.030 , which means that $t$ is more significant than the $t$ table so that the research hypothesis is accepted.

The competency variable value has a significant level of 0.023 . This value is less than 0.05 . This means that the research hypothesis states that competence has a partial effect on audit quality and is accepted. In this case, the $t$ count has a value of 3.934 , while the t table's value is 2.030 , which means that $t$ is more significant than the $t$ table, so the research hypothesis is accepted.

The value of the independent variable has a significant level of 0.014 . This value is less than 0.05 . This means that the research hypothesis, which states that independence has a partial effect on audit quality is accepted. In this case, the $t$ count has a value of 5.634, while the $t$ table's value is 2.030 , which means that $t$ is more significant than the $t$ table so that the research hypothesis is accepted.

The value of the Auditor Work Experience variable has a significant level of 0.009 . This value is less than 0.05 . This means that the research hypothesis states that the Auditor's Work Experience has a partial effect on audit quality and is accepted. In this case, the $t$ count has a value of 5.891, while the $t$ table's value is 2.030 , which means that $\mathrm{t}$ is more significant than the $\mathrm{t}$ table, so the research hypothesis is accepted.

\section{Discussion}

\section{Analysis of the Effect of Professionalism on Audit Quality}

Based on the analysis results, the professionalism variable has a count of 4.490 and a significance value of 0.027 $<0.05$. Here it shows that professionalism affects audit quality so that $\mathrm{H} 1$ is accepted. Thus it can be said that professionalism must always be maintained consistently to maintain the reputation of the profession. Professionalism is essential to maintain audit quality by always increasing specific knowledge and training. When an auditor has a high level of knowledge, the audit procedure will run smoothly without any obstacles. The auditor can also be more sensitive to the client's situation and conditions so that the auditor can easily find the client's mistakes. The auditor will provide conclusions on the audit results under the client's actual conditions.

The results of this study are consistent with research by Sriyanti \& Jianto (2019), Safaroh, Susilawati \& Halim (2016), Mardijuwono \& Subianto (2018), which state that professionalism affects audit quality.

\section{Analysis of the Effect of Competence on Audit Quality}

Based on the analysis results, the competency variable has a count of 3,934 and a significance value of $0.023<0.05$. Here it shows that objectivity affects audit quality so that $\mathrm{H} 2$ is accepted. Thus, the higher the competence possessed by an auditor, the better the resulting audit quality. A competent auditor will certainly review the analysis and interviews in producing the audited report to make it more accurate. The first general standard in SPAP states that audits must be carried out by one or more persons who have sufficient technical training expertise as an auditor. This study's results are consistent with the research of Furiady \& Kurnia (2015), Ningrum \& Wedari (2017), which states that objectivity affects audit quality.

\section{Analysis of the Effect of Independence on Audit Quality}

Based on the analysis results, the independent variable has a count of 5.634 and a significance value of $0.014<0.05$. Here it shows that independence affects audit quality so that $\mathrm{H} 3$ is accepted. Thus, it can be said that during the preparation of the audit program, there is no emotional and financial influence on the client-side, and there is no interference from the leadership to determine, eliminate or modify the parts to be examined. And at the time of reporting, there was no intervention from outside parties to influence the facts reported. The auditors in charge are not in anyone's interests, be it management or company owners, creditors, or parties who place their trust in the auditor's report. Therefore, an independent auditor will maintain an honest attitude, not taking sides with anyone, so that the resulting audit results are objective and can be trusted by all interested parties. 
Vol: 2, Issue: 4

April/2021

https://ijbssrnet.com/index.php/ijbssr

DOI: http://dx.doi.org/10.47742/ijbssr.v2n4p2

http://iarpnet.org/

The results of this study are consistent with research by Sriyanti \& Jianto (2019), Giovani \& Rosyada (2019), Mardijuwono \& Subianto (2018), Iryani (2017), Pandoyo (2016), which state that independence influences audit quality.

\section{Analysis of the Effect of Auditor's Work Experience on Audit Quality}

Based on the analysis results, the auditor's work experience variable has a count of 5.891 and a significance value of $0.009<0.05$. Here it shows that the work experience of auditors affects audit quality so that $\mathrm{H} 4$ is accepted. Thus, it can be said that based on the work experience he has gained in fulfilling and overcoming problems in the field, an auditor will be better able to explain the audit findings. More experienced auditors also have good accuracy and skills in completing each job and are better able to provide reasonable explanations for errors in financial statements and classify errors based on audit objectives and the structure of the underlying accounting system. The results of this study are consistent with research by Yonchers (2019), Sriyanti \& Jianto (2019), Ningrum \& Wedari (2017), S. Zahmatkesh \& J. Rezazadeh (2017), which state that auditor work experience affect audit quality. However, this study is not consistent with the research of Furiady \& Kurnia (2015).

\section{CONCLUSIONS}

Based on the results of the analysis and discussion that has been stated above, the following conclusions are obtained:

1. Professionalism has a positive influence on Audit Quality. This is evidenced by the count of 4.490, which is greater than the $\mathrm{t}$ table, which is 2.030 with a significant $\mathrm{p}$-value of $0.027<0.05$.

2. Competence has a positive effect on Audit Quality, where this is evidenced by the count of 3.934 which is greater than the table of 2.030, with a significant $\mathrm{p}$-value of $0.023<0.05$.

\section{References}

A Putu, R.C.N., \& P. Dyan Y.S., 2013. pengaruh kompetensi, independensi, dan time budget pressure terhadap kualitas audit. EJurnal Akuntansi, Vol 4, No 1, pp. 92-109. Available at: https://ojs.unud.ac.id/index.php/Akuntansi/article/view/5896

Ade, D.V.G., \& Dini, R., 2019. Pengaruh kompetensi dan independensi auditor terhadap kualitas audit pada kantor akuntan publik di makassar. Jurnal Akuntansi Netral, Akuntabel, Objektif, Vol 2, No. 2. Available at: http://jurnal.untad.ac.id/jurnal/index.php/jan/article/view/12830

Agus Widodo, M., \& Charis, S., 2018. Independence, professionalism, professional skepticism The relation toward the resulted audit quality. Asian Journal of Accounting Research Vol. 3 No. 1, pp. 61-71. Available at:

http://www.emeraldinsight.com/2443-4175.htm.

Arens, Alvin A. Elder, Randal J. Beasley, Mark S. 2008. Auditing dan jasa Assurance. Jakarta : Penerbit Erlangga

Danang, F., \& Agus , E., Pengaruh Independensi, Kompetensi, Integritas, Objektifitas dan Pengalam Kerja Auditor Terhadap Kualitas Audit. Seminar Nasional dan the 3rd call for syariah Paper.

Darmawan, D., Sinambela, E. A., \& Mauliyah, N. I. 2017. The Effect of Competence, Independence and Workload on Audit Quality. Journal of Academic Research and Sciences (JARES), 2(2), 5. Available at: https://doi.org/10.30957/jares.v2i2.404

Elisha, M.S., \& Icuk, R.B., 2010. Pengaruh independensi, pengalaman, due professional care dan akuntabilitas terhadap kualitas audit. Siposium Nasional Akuntansi. Available at : www.sna13purwokerto.com

Enung Nurhayati., 2015. Pengaruh Pengalaman, Independensi, dan Time Budget Pressure Terhadap Kualitas Audit dengan Etika Sebagai Variabel Pemoderasi. journal.uniku.ac.id Vol 1, No 2. Available at:

http://journal.uniku.ac.id/index.php/jrka/article/view/438 
Vol: 2, Issue: 4

April/2021

https://ijbssrnet.com/index.php/ijbssr

DOI: http://dx.doi.org/10.47742/ijbssr.v2n4p2

Fabio, F.Y., 2019. pengaruh independensi, profesionalisme dan pengalaman auditor terhadap kualitas audit dengan etika auditor sebagai variabel moderasi. artikel ilmiah. available at : http://eprints.perbanas.ac.id/5524/1/artikel\%20ilmiah.pdf.

Gita, S.N., Linda, K.W., 2017. impact auditor's work experience, independence, objectivity, integrity, competency, and accountability on audit quality. Journal of Economics \& Busines, Vol. 01 No.01, 019-033. Available at: http://www.jebiatmajaya.com.

Hery, 2019. Auditing Dasar-dasar Pemeriksaan Akuntansi. [e-book]. Jakarta: PT.Grasindo https://books.google.co.id/books [diakses 25 Juni 2020]

Isnaini, S., R Anastasia, E.S., \& Abdul, H., 2016. Pengaruh Independensi, Profesionlisme, Rotasi Public Accounting Office, dan Anggaran Waktu terhadap Kualitas Audit. Journal Riset Mahasiswa. Available at:

https://www.neliti.com/id/publications/192847.

Kurnia, W., Khomsiyah, K., \& Sofie, S. 2014. Pengaruh Kompetensi, Independensi, Tekanan Waktu, Dan Etika Auditor Terhadap Kualitas Audit. Jurnal Akuntansi Trisakti, 1(2), 49. Available at : https://doi.org/10.25105/jat.v1i2.4826

Lia, D.I., 2017. The Effect of Competence, Independence, and Professional Auditors to Audit Quality. Journal of humanities and social studies, Vol. 01, No 01. Available at: https://journal.unpak.ac.id.

Mardijuwono, A. W., \& Subianto, C., 2018. Independence, professionalism, professional skepticism. Asian Journal of Accounting Research, 3(1), 61-71. Available at: https://doi.org/10.1108/ajar-06-2018-0009.

Mathius, T., 2016. Kualitas Audit dan Pengukurannya. [e-books]. Alfabeta https://repository.maranatha.edu [diakses 25 Juni 2020]

Messier \& Glover \& Prawitt. 2006. Auditing Services \& Assurance a systematic Approach, Buku dua, Edisi 3, Diterjemahkan oleh Nori Hinduan, Penerbit Salemba Empat.

Nuri Fimartsani., 2018. pengaruh kompetensi, independensi danprofesionalisme terhadap kemampuan auditor dalam mendeteksi kecurangan (fraud). Institutional respositories \& Scientific journal. Available at $:$ http://repository.unpas.ac.id/id/eprint/37118

Olivia, F., \& Ratnawati, K., 2015. The Effect of Work Experiences, Competency, Motivation, Accountability, and Objectivity towards Audit Quality. Procedia - Social and Behavioral Sciences 211.328 - 335. Available at: http://www.sciencedirect.com

Pandoyo., 2016. The effect of auditor competence, independence, audit experience, organizational culture, and leadership against auditor professionalism and its implication on audit quality. International Journal of Advanced Research, Vol 4, No. 5, 16321646. Available at: http://www.journalijar.com.

Putu, S.F., \& Gede, J., 2014. Pengaruh Independensi, Profesionalisme, Tingkat Pendidikan, Etika Profesi, Pengalaman, dan Kepuasan Kerja Auditor pada Kualitas Audit Kantor Akuntan Publik di Bali. E-Jurnal Akuntansi Universitas Udayana,444461. Available at : https://ojs.unud.ac.id/index.php/Akuntansi/article/view/8918

Retno, S., \& Jianto., 2019. Pengaruh profesionalisme, pengalaman kerja dan independensi auditor terhadap kualitas audit. Jurnal Ekonomi Akuntansi, Vol 4, No.1, Hal 67-84. Available at : https://jurnal.untag-sby.ac.id/index.php/JEA17/article/view/3289.

Rizky Darmawan., 2016. Pengaruh Skepsitsme Profesional, Independensi, Integritas, Serta Komepetensi Auditor Terhadap Kualitas Audit. jurnalmahasiswa.unesa.ac.id, Vol 5, No 1. Available at: https://jurnalmahasiswa.unesa.ac.id/index.php/jurnalakuntansi/article/view/17850

Septriani., \& Yossi., 2012. Pengaruh independensi dan kompetensi auditor terhadap kualitas audit. Jurnal Akuntansi \& Manajemen, Vol 7, No 2, Hal 78-100. Available at : http://www.polinpdg.ac.id

Surroh Zu'amah., 2009. Independensi dan kompetensi auditor pada opini audit. Journal Dinamika Akuntansi, Vol 1, No 2. Available at: http://journal.unnes.ac.id/index.php/jda

Tia yulistiani., 2019. Pengaruh kondisi keuangan, kualitas audit, pertumbuhan perusahaan dan ukuran perusahaan terhadap penerimaan opini audit going concern. Institutional respositories \& Scientific journal. Available at:

http://repository.unpas.ac.id/id/eprint/43015

Yunus, F., dkk., 2012. Pengaruh Pengalaman Kerja Otonomi Kerja, dan Tekanan Peran Terhadap Kinerja Auditor pada Kantor Akuntan Publik di Bandar Lampung. Jurnal.ubl.ac.id, Vol 3. No 2. Available at:

http://jurnal.ubl.ac.id/index.php/jak/article/view/235

Zahmatkesh, S., \& Rezazadeh, J., 2017. The effect of auditor features on audit quality. Review of Applied Management Studies, No. 09. Available at: http://dx.doi.org/10.1016/j.tekhne.2017.09.003 